\title{
Variations in the Facial Dimensions and Face Types among the Students of A Medical College
}

\author{
Anup Pandeya, ${ }^{1}$ Alok Atreya ${ }^{2}$ \\ 'Department of Anatomy, Devdaha Medical College and Research Institute, Devdaha, Rupandehi, Nepal, ${ }^{2}$ Department of \\ Forensic Medicine, Devdaha Medical College and Research Institute, Devdaha, Rupandehi, Nepal.
}

Introduction: Facial dimensions and the face types are the most variable factors in human community. These dimensions have practical implications for the anthropologist, forensic experts, anatomists and surgeons. The present study is aimed to determine the facial dimensions and face types among the medical and nursing students.

Methods: A cross-sectional study was done among medical and nursing students of Devdaha Medical College and Devdaha College of Science and Technology from January 2017 to February 2018. There were 155 students of which 72 were males and 83 females. Facial height and width were measured and facial index was calculated. The collected data was entered and analyzed in SPSS 21 and differences in measurements among males and females were calculated.

Results: The mean facial height among the total population was $10.83 \pm 0.74 \mathrm{~cm}$ and facial width was $12.39 \pm 0.67 \mathrm{~cm}$ with the mean facial index of $87.44 \pm 4.82$. The most prevalent was the mesoprosopic face $(n=59,38.06 \%)$ followed by leptoprosopic $(n=43,27.74 \%)$. The least prevalent face type was hyperleptoprosopic $(n=7,4.52 \%)$ which was observed only in male individuals.

Conclusions: The present study depicts higher values of facial height, width and facial indexfor males when compared to the females. The present finding is based upon the indices and classification obtained from developed nation. Further studies with local data would help develop indices and classification for Nepalese population.

Keywords: anthropometry; facial height; facial index; facial width.

\section{INTRODUCTION}

Every individual is unique in their facial characters. These charactersvary with different ethnic groups, body form and proportions. ${ }^{1}$ Anthropometric analysis is a noninvasive quantitative method employed to determine the measurements of the different body parts in either living or dead for scientific purposes. ${ }^{2}$ It has been used for the sex determination, estimation of height and other medico-legal purposes by anthropologists and forensic scientists. ${ }^{3}$ At birth the development of face is completed by $40 \%$ followed by $65 \%$ within next 7 years and growth in the bizygomatic width by $15 \%$ within 10 years. ${ }^{4}$ Shape of face depends on many factors like gender, ethnicity, socio-economic, nutritional, genetic factors and climate. ${ }^{5-7}$ Facial index has been categorized as hypereuroprosopic, europrosopic, mesoprosopic, leptoprosopic and hyperleptoprosopic on the basis of percentage values of facial breadths and lengths. ${ }^{8}$ This study is aimed to determine the variations in facial morphometry amongst the medical students.

Correspondence: Anup Pandeya, Department of Anatomy, Devdaha Medical College and Research Institute, Devdaha, Rupandehi, Nepal. Email: anup.bpkihs@gmail.com, Phone: +977-9841461364. 
Pandeya et al. Variations in the Facial Dimensions and Face Types among the Students of a Medical College

\section{METHODS}

A cross-sectional study was done among the students of Devdaha Medical College and Devdaha College of Science and Technology from January 2017 to February 2018. The ethical approval was taken from ethical committee of Devdaha Medical College and Research Institute prior to the study. There were 155 students who participated in the study including 72 males and 83 females. The participants were informed about the study protocols and personal identifier was removed before the data collection. The study participants were asked to sit in a relaxed state looking forward straight. Anthropometric measurements were obtained by using Vernier callipers. The variables were recorded as age, sex, facial height and facial width.

The facial height was measured in centimetres $(\mathrm{cm})$ from the nasion (the point in the nose crossed by the mid-sagittal plane and naso-frontal sutures) to the gnathion (the lowest point of mandible where the midsagittal plane intersects the lower margin of lower jaw). Facial width was measured in $\mathrm{cm}$ between the right and left zygion (the lateral most point on the zygomatic arch). Facial index was calculated by using the formula, Facial index $(\mathrm{FI})=($ Facial width $/$ Facial height $) \times 100$. It was again categorized into five different face shapes by using the Banister's classification. The five face types are hypereuroprosopic (very broad face, $\mathrm{FI}=<80$ ), europrosopic (broad face, $\mathrm{FI}=80-85$ ), mesoprosopic (round face, $\mathrm{FI}=85-90$ ) leptoprosopic (long face, $\mathrm{FI}=90$ 95) and hyperleptoprosopic (very long face, $\mathrm{FI}=>95$ ). The collected data was then entered and analyzed by using SPSS 21. The descriptive analysis was performed for frequency, mean and standard deviation (SD). Student's t-test was employed to compare the means between the facial width and facial height within the study participants. The inclusion criteria were: a) those participants who had no craniofacial asymmetry; b) those who had no history of orthodontic treatment; c) those who had no history of facial bone fracture and d) those who consented for the study. The exclusion criteria were: a) those having craniofacial asymmetry; b) those having history of facial trauma and fracture; c) those participants who had undergone orthodontic treatment and d) those participants who did not consent to participate.

\section{RESULTS}

The present study comprised of 155 medical and nursing students of which $72(46.45 \%)$ were males and $83(53.55 \%)$ females respectively. The mean value of both facial height and facial width were slightly higher in male participants (Table 1).

\begin{tabular}{|llllll|}
\hline \multicolumn{6}{|l}{ Table 1. Mean and SD of facial height and facial width among medical students. } \\
\hline Sex & Total $(\mathbf{n})$ & $\begin{array}{l}\text { Facial height }(\mathbf{c m}) \\
\text { Mean } \pm \text { SD }\end{array}$ & $\begin{array}{l}\text { Range of facial } \\
\text { height }(\mathbf{c m})\end{array}$ & $\begin{array}{l}\text { Facial width }(\mathbf{c m}) \\
\text { Mean } \pm \text { SD }\end{array}$ & $\begin{array}{l}\text { Range of facial } \\
\text { width }(\mathbf{c m})\end{array}$ \\
\hline Male & 72 & $11.31 \pm 0.47$ & $10.10-13.00$ & $12.69 \pm 0.64$ & $11.2-15.1$ \\
Female & 83 & $10.41 \pm 0.68$ & $9.30-12.60$ & $12.14 \pm 0.60$ & $11.1-13.7$ \\
Total & 155 & $10.83 \pm 0.74$ & $9.30-13.00$ & $12.39 \pm 0.67$ & $11.1-15.1$ \\
\hline
\end{tabular}

The range of facial index was higher in males with the mean $(89.33 \pm 5.02)$ when compared to females $(85.80 \pm 4.00)$. The facial index values among male and female participants were statistically significant (Table 2).

\begin{tabular}{|c|c|c|c|}
\hline Sex & $\begin{array}{l}\text { Facial index } \\
\text { range }\end{array}$ & $\begin{array}{l}\text { Facial index } \\
\text { Mean } \pm \text { SD }\end{array}$ & $P$-value \\
\hline Male & $75.18-100.00$ & $89.33 \pm 5.02$ & $<0.001$ \\
\hline Female & $77.69-92.68$ & $85.80 \pm 4.00$ & $<0.001$ \\
\hline Combined & $75.18-100.00$ & $87.44 \pm 4.82$ & $<0.001$ \\
\hline
\end{tabular}

Face types were categorized as hypereuroprosopic, europrosopic, mesoprosopic, leptoprosopic and hyperleptoprosopic as per FI value (Table 3).

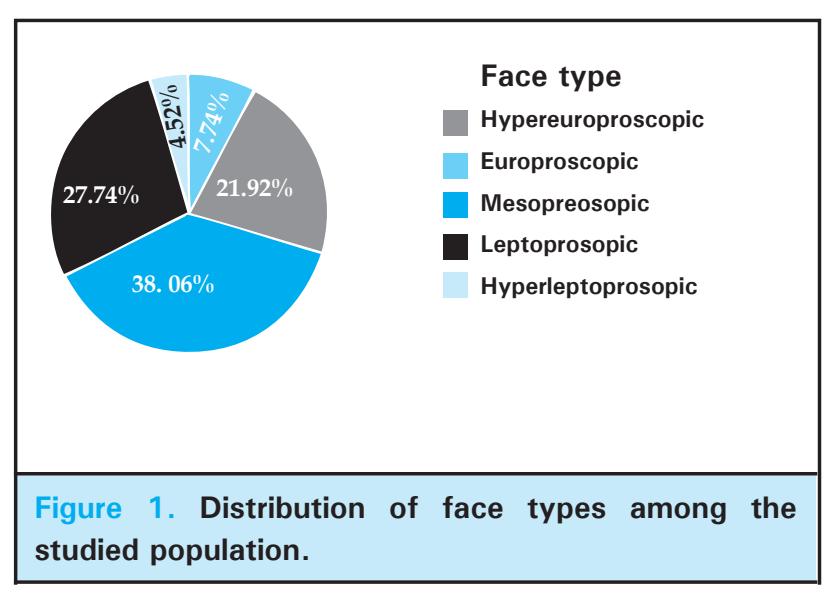


Pandeya et al. Variations in the Facial Dimensions and Face Types among the Students of a Medical College

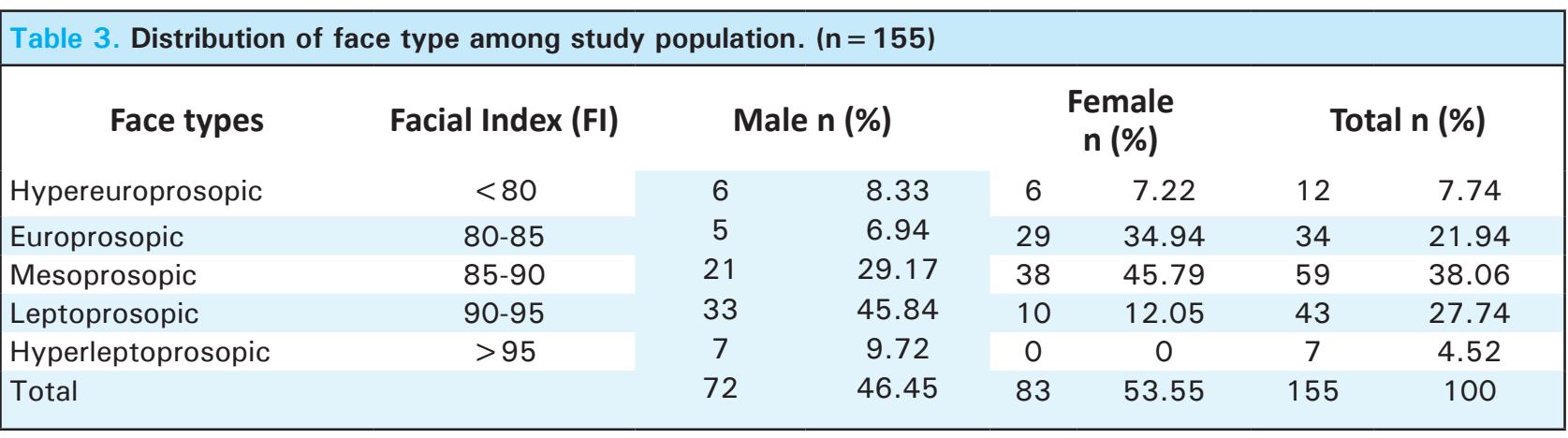

In males, leptoprosopic faces were prevalent $(n=33$, $45.84 \%)$ whereas mesoprosopic face were dominant in the females ( $n=38,45.79 \%)$. The prevalent face type in both the gender was mesoprosopic ( $n=59,38.06 \%)$ and least prevalent was hyperleptoprosopic $(n=7,4.52 \%)$. Europrosopic face type was the least prevalent face in males ( $n=5,6.94 \%$ ) whereas hyperleptoprosopic face type was rare in females.

\section{DISCUSSION}

Facial dimensions and facial index varies with gender and ethnic groups. ${ }^{9-12}$ The mean facial height of Nepalese male and female from the present study were lower than the measurements obtained from Sri Lanka $(12.56 \pm 0.93 \mathrm{~cm}$ in male and $12.00 \pm 0.64 \mathrm{~cm}$ in female respectively)..$^{13}$ In contrast, Nepalese population had wider face when compared to Sri Lankan population $(12.00 \pm 0.64 \mathrm{~cm}$ in male and $10.99 \pm 0.77 \mathrm{~cm}$ in females respectively). ${ }^{13}$ However, measurement of mean facial height and width of both Nepalese males and females were very close to Malaya population. ${ }^{8}$ When the facial index is compared with Sri Lankan and Serbian population, Nepalese population had lower values. ${ }^{13,14}$ Studies conducted in Central Serbia and Sri Lanka reported the hypereuroprosopic face as the least dominant face types which is in contrast with the findings of the present study. ${ }^{13,14}$ Our study revealed narrow faced females were rare andit is believed that hyperleptoprosopic (narrow face) males are regarded as more attractive by females. ${ }^{15}$ It might be due to the fact that men with wider faces are more aggressive, dominant and status seeking. ${ }^{16}$ Infidelity is also linked to wider faced males with higher FI. ${ }^{17}$
19 The person with higher $\mathrm{FI}$ is supposed to be more aggressive, uncooperative and intolerant than those with lower Fl. ${ }^{16,20}$ The facial index is used as a tool for orthodontic treatment. ${ }^{21}$ The facial index is also related to masculinity. There is an association of facial index to testosterone level. ${ }^{22}$ From the forensic point of view, the facial indices can be used as an instrument of dentification. ${ }^{23}$ The more prevalent face type of the given population can be used to construct the facial features of exhumed skull. Although the study has met its aim, further studies are sought in different ethnic and age groups in different regions of the country to generalize the findings as the national statistics of the facial dimensions and face type.

\section{CONCLUSIONS}

The present study depicts higher values of facial height, width and facial index for males when compared to the females. The present finding is based upon the indices and classification obtained from developed nation. Further studies with local data would help develop indices and classification for Nepalese population.

\section{ACKNOWLEDGEMENTS}

The authors would like to thank all the participants of thisstudy in Devdaha Medical College and Research Institute as well as Devdaha College of Science and Technology, Rupandehi, Nepal and those who have helped during the data collection and for the preparation of the manuscript.

Conflicts of Interest : None.

\section{REFERENCES:}

1. Ngeow WC, Aljunid ST. Craniofacial anthropometric norms of Malays. Singapore Med J. 2009;50(5):525-8. [PubMed]

2. FarkasLG, DeutschCK. Anthropometric determination of craniofacial morphology. Am J Med Genet. 1996;65(1):1-4. [PubMed]
3. Kamal R, Yadav PK. Estimation of stature from different anthropometric measurements in Kori population of North India. Egypt J Forensic Sci. 2016;6(4):468-77. [Full Text | DOI]

4. Scott JH. The Growth of the Human Face. Proc R Soc Med. 


\section{4;47(2):91-100. [PubMed]}

5. Franciscus RG, Long JC. Variation in human nasal height and breadth. Am J Phys Anthropol. 1991;85(4):419-27. [PubMed]

6. Porter JP, Olson KL. Analysis of the African American female nose. Plast Reconstr Surg. 2003;111(2):620-6. [PubMed]

7. Zhang XT, Wang SK, Zhang W, Wang XF. Measurement and study of the nose and face and their correlations in the young adult of Han nationality. Plast Reconstr Surg. 1990;85(4):532-6. [PubMed]

8. Yesmin T, Thwin SS, Urmi SA, Wai MM, Zaini PF, Azwan K. A study of facial index among Malay population. J Anthropol. 2014;1-5. [DOI | Full Text]

9. Jahanshahi M, Golalipour MJ, Heidari K. The effect of ethnicity on facial anthropometry in Northern Iran. Singapore Med J. 2008;49(11):940-3. [PubMed]

10. Heidari Z, Mahmoodzadeh sagheb HR, Mohammadi M, Noori Moogehi SMH, Arab A. Cephalic And Prosopic Indices: Comparison In One-Day Newborn Boys In Zahedan. Tehran Univ Med J. 2004;62(2):156-65. [Full Text]

11. Pandey AK. Cephalo-facial Variation Among Onges. The Anthropologist. 2006;8(4):245-9. [DOI]

12. Raji J, Garba S, Numan A, Waziri M, Maina M. Morphological evaluation of head and face shapes in a North-Eastern Nigerian population. Aust J Basic Appl Sci. 2010;4:3338-41. [Full Text]

13. Chandimal K, Yasawardene S, Adikari G. Assessment of Prosopic Phenotypes in Purana (old) Inhabitants at Sigiriya Suburbs, Sri Lanka. Int J Adv Sci Tech. 2015;3:93-96. [Full Text]

14. Jeremić D, Kocić S, Vulović M, Sazdanović M, Sazdanović $\mathrm{P}$, Jovanović B, et al. Anthropometric study of the facial index in the population of central Serbia. Arch Biol Sci. 2013;65(3):1163-8. [DOI | Full Text]
15. Puts DA. Beauty and the beast: mechanisms of sexual selection in humans. Evol Hum Behav. 2010;31(3):157-75. [DOI]

16. Geniole SN, Denson TF, Dixson BJ, Carré JM, McCormick CM.Evidence from Meta-Analyses of the Facial Width-to-Height Ratio as an Evolved Cue of Threat. PLoS One. 2015;10(7):e0132726. [PubMed | DOI]

17. Dixson BJW. Is Male Facial Width-to-Height Ratio the Target of Sexual Selection? Arch Sex Behav.2018 March 5. [PubMed I DOI]

18. Wang Y, Geigel J, Herbert A. Reading personality: Avatar vs. human faces. Proc-2013 Hum Assoc Conf Affect Comput Intell Interact ACII. 2013; 479-484. [DOI]

19. Geniole SN, Molnar DS, Carré JM, McCormick CM. The facial width-to-height ratio shares stronger links with judgments of aggression than with judgments of trustworthiness. J Exp Psychol Hum Percept Perform. 2014;40(4):1526-41. [PubMed | DOI]

20. Archer J. Does sexual selection explain human sex differences in aggression? Behav Brain Sci. 2009;32:249-66. [PubMed | DOI]

21. Torres-Restrepo AM, Quintero-Monsalve AM, Giraldo-Mira JF, Rueda ZV, Vélez-Trujillo N, Botero-Mariaca P. Agreement between cranial and facial classification through clinical observation and anthropometric measurement among Envigado school children. BMC Oral Health. 2014;14:50. [ PubMed | DOI ]

22. Lefevre CE, Lewis GJ, Perrett DI, Penke L. Telling facial metrics: Facial width is associated with testosterone levels in men. Evol Hum Behav. 2013;34(4):273-9. [DOI]

23. Vanezis M, Vanezis P. Cranio-facial reconstruction in forensic identification--historical development and a review of current practice. Med Sci Law. 2000;40(3):197-205. [PubMed] 